\title{
UUMM II \\ - det Ultimative UM-Møde II 2007
}

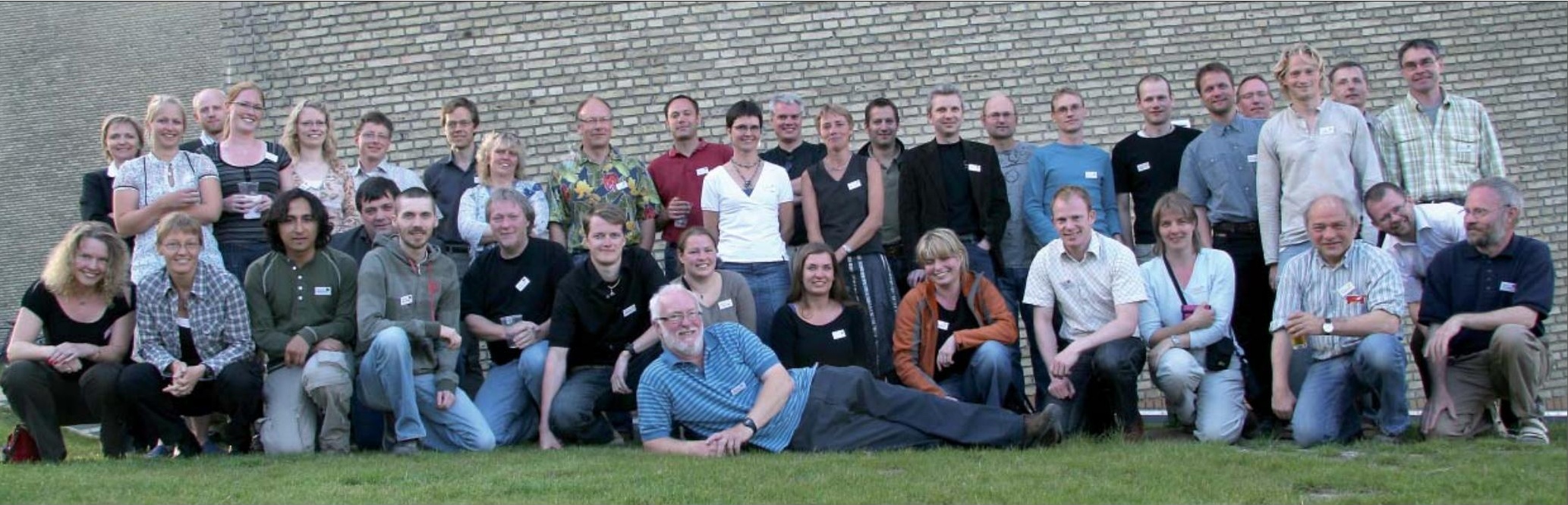

Stående fra venstre: Anita Holmboe (27), Maria Rasch (59), Morten Riishuus (42), Tine Kristensen (51), Anne Binderup Sørensen (53), Per Gisselø (31), Peter Naldal (18), Britta Paasch (15), Lars Knudsen (9), Frederik Thayssen (29), Tina Rasmussen (21), Anders Pedersen (24), Helle Holdam (10), Kim Kock Hansen (28), Jens Kirkegaard (16), Pål Thjømøe (26), Jakob Kløve Jakobsen (47), Kasper Leth Lundgaard (41), Henrik Schiellerup (14), Knud Aage Nielsen (19), Lars Peter Salmonsen (60), Niels Nybo Jakobsen (6), Henning Sund Sørensen (12). Siddende fra venstre: Ulla Hjuler, Susanne Plesner (38), Benjamin Heredia (58), Jørn Jensen (11), Peter Thomadsen (54), Frank Møller Nielsen (8), Jacob Skøtt (55), Anna-Maria Nielsen (57), Lise Fryland Jensen (56), Karin Josephsen (43), Heine Buus (46), Gurli Meyer (25), Ole Engell Sørensen (5), Christian Tegner (13), Jon Svane (4). Liggende: Richard Wilson (0). Tallet i parantese efter navnet er "UM-nummeret" - rækkefølgen for afslutning af uddannelsen. (Foto: Christian Tegner).

Af J. Richard Wilson, Geologisk Institut, Aarhus Universitet

Richard Wilson har haft rigtigt mange studerende gennem sin tid som lektor på Geologisk Institut i Århus, og for anden gang siden 2003 mødtes han med mange af sine gamle og nuværende studerende 19. maj - 38 ud af 60 UM-medlemmer var mødt op.

I 1986 var jeg sammen med nogle specialestudenter på feltarbejde i Sydnorge. Under en middag i villateltet blev det forslået, at vi skulle mødes regelmæssigt til socialt samvær, når vi var tilbage i Århus. Det var nødvendigt at finde et passende navn - og vi besluttede at kalde gruppen for "Ultramafia" - UM.

\section{Ultramafisk!}

De fleste har hørt om mafia; ultramafia er så den hårde kerne af mafia. Den kendsgerning, at mange af specialestudierne om- handlede ultramafiske bjergarter (magmatiske bjergarter med $>90 \%$ mørke mineraler), var selvfølgelig ikke uvæsentlig! UM har nu eksisteret i 21 år. Vi (de aktive studerende, nogle af dem på billedet samt forfatteren) mødes tre-fire gang om året og spiser noget godt samt drikker medbragte væsker. Det betyder, at vi møder hinanden på tværs af årgange. De "nye” studenter lærer de “ældre" speciale- og ph.d.-studenter at kende.

Under perioder med de store årgange krævede det, at man havde god plads til at holde et UM-møde med op til 15 deltagere. I skrivende stund er det mindre krævende - jeg har ingen specialestudenter for første gang i >30 år!

\section{UM gennem årene}

Der er 60 medlemmer af UM nu. Mine første specialestudenter blev færdige, før UM blev opfundet. De har fået UM-numrene 16. UM-medlem nr. 13 (Christian Tegner) er nu lektor på Geologisk Institut, Aarhus Universitet. Han var/er vejleder for de såkaldte “andengenerations-UM'er" (46, 47, 48, 50, $53,54,57,58,60)$. Af de 60 medlemmer var de 38 med til UUMM-II. Blandt dem var der tilrejsende fra blandt andet Norge, Island og Bornholm. Nogle, der gerne vil have været med, blev forhindret på grund af arbejde i for eksempel USA, Egypten og Spanien. Mødet i år var det andet, hvor UMmedlemmerne igennem årene blev samlet. Det første UUMM-møde var i maj 2003. I år kunne vi blandt andet vise vores nye lokaler i det gamle kunstmuseum i bygning 1670 frem.

Mange UM-medlemmer har arbejdet på lagdelte intrusioner i Norge (Fongen-Hyllingen 19; Bjerkreim-Sokndal 8; andre 5) eller Grønland (4); andre på dykes/sills forskellige steder i verden (8). Der har også været nogle (5), der har arbejdet på Kap Verde Øerne i samarbejde med en gruppe fra Københavns Universitet.

At få den nødvendige opbakning til at kunne samle så mange af mine tidligere studenter har været overvældende positiv. Da vi sad i teltet i 1986 og oprettede UM, havde jeg ikke forestillet mig, at det vil føre til så mange vidunderlige oplevelser med så mange dejlige mennesker! 